Review

\title{
Vasopressor-Sparing Strategies in Patients with Shock: A Scoping-Review and an Evidence-Based Strategy Proposition
}

\author{
Pierre-Grégoire Guinot ${ }^{1,2, *}$, Audrey Martin ${ }^{1}$, Vivien Berthoud ${ }^{1}$, Pierre Voizeux ${ }^{1}$, Loic Bartamian ${ }^{1}$, \\ Erminio Santangelo ${ }^{1}$, Belaid Bouhemad ${ }^{1,2}$ and Maxime Nguyen ${ }^{1,2}$ (D) \\ 1 Department of Anesthesiology and Intensive Care, CHU Dijon, 21000 Dijon, France; \\ audrey.martin@chu-dijon.fr (A.M.); viven.berthoud@chu-dijon.fr (V.B.); pierre.voizeux@chu-dijon.fr (P.V.); \\ loic.bartamian@chu-dijon.fr (L.B.); erm.santangelo@gmail.com (E.S.); belaid.bouhemad@chu-dijon.fr (B.B.); \\ maxime.nguyensoenen@gmail.com (M.N.) \\ 2 Lipness Team, INSERM Research Center LNC-UMR1231 and LabEx LipSTIC, University of Burgundy, \\ 21000 Dijon, France \\ * Correspondence: guinotpierregregoire@gmail.com
}

check for

updates

Citation: Guinot, P.-G.; Martin, A.; Berthoud, V.; Voizeux, P.; Bartamian,

L.; Santangelo, E.; Bouhemad, B.;

Nguyen, M. Vasopressor-Sparing

Strategies in Patients with Shock: A Scoping-Review and an EvidenceBased Strategy Proposition. J. Clin. Med. 2021, 10, 3164. https://doi.org/ $10.3390 / \mathrm{jcm} 10143164$

Academic Editor: Richard Mario Pino

Received: 17 May 2021

Accepted: 16 July 2021

Published: 18 July 2021

Publisher's Note: MDPI stays neutral with regard to jurisdictional claims in published maps and institutional affiliations.

Copyright: (c) 2021 by the authors. Licensee MDPI, Basel, Switzerland. This article is an open access article distributed under the terms and conditions of the Creative Commons Attribution (CC BY) license (https:/ / creativecommons.org/licenses/by/ $4.0 /)$.

\begin{abstract}
Despite the abundant literature on vasopressor therapy, few studies have focused on vasopressor-sparing strategies in patients with shock. We performed a scoping-review of the published studies evaluating vasopressor-sparing strategies by analyzing the results from randomized controlled trials conducted in patients with shock, with a focus on vasopressor doses and/or duration reduction. We analyzed 143 studies, mainly performed in septic shock. Our analysis demonstrated that several pharmacological and non-pharmacological strategies are associated with a decrease in the duration of vasopressor therapy. These strategies are as follows: implementing a weaning strategy, vasopressin use, systemic glucocorticoid administration, beta-blockers, and normothermia. On the contrary, early goal directed therapies, including fluid therapy, oral vasopressors, vitamin C, and renal replacement therapy, are not associated with an increase in vasopressor-free days. Based on these results, we proposed an evidence-based vasopressor management strategy.
\end{abstract}

Keywords: vasopressor; shock; norepinephrine; sepsis; weaning

\section{Introduction}

Because fluid and vasopressors are the main treatments for shock, they are used on a day-to-day basis as symptomatic treatment for arterial hypotension. Vasoplegia is associated with vasodilation and vascular hypo-responsiveness, and involves multiple mechanisms [1]. The aim of vasopressor therapy is to restore organ perfusion so as to limit the risk of multiple organ failure and death. For several years, the published literature regarding the different types of vasopressors (catecholaminergic and non-catecholaminergic agents) has grown considerably. Most of this literature has studied superiority in terms of death or specific clinical outcomes (e.g., acute kidney failure or arrythmia) [2-4]. Despite the emergence of new vasopressor agents, norepinephrine is still the recommended first-line agent [5]. One problem with the use of vasopressors is the risk of side effects and the ensuing need for intensive care management, which is costly. Studies have demonstrated that vasopressor use can be associated with specific side effects, and prolonged use may be associated with mortality [6,7]. A study has demonstrated that implementing vasopressor sparing strategies is associated with lower morbidity and ICU (intensive care unit) length of stays [7]. Numerous reviews have investigated the different types of vasopressors and their hemodynamic effects [1,8-11], but, to date, no review has specifically focused on therapeutic and non-therapeutic strategies associated with the sparing effect for vasopressor use. Thus, we do not have meta-analyses or reviews evaluating the vasopressor-sparing strategies.

Our objective was to perform a scoping-review of the published studies evaluating the vasopressor-sparing strategies. We therefore analyzed the results from randomized 
controlled trials (RCTs) conducted in patients with shock, focusing on vasopressor doses and/or duration reduction.

\section{Materials and Methods}

\subsection{Population}

We aimed to study vasopressor-sparing strategies in adult patients with shock. We conducted a scoping-review by following PRISMA-scoping review guidelines [12]. Because of its nature, the present scoping-review could not be registered (refusal from Prospero).

\subsection{Criteria}

The inclusion criteria were RCT studies (with parallel groups), with at least one of the reported outcomes including vasopressors. Outcomes were classified as follows: (1) shock reversal, (2) duration of vasopressor use, (3) day free of vasopressors, (4) cumulative dose of vasopressors, and (5) dose of vasopressors.

The exclusion criteria were as follows: articles not available in English, as well as those on traditional Chinese medicine, anaphylactic shock, and reporting COVID-19.

Studies with non-significant outcomes in terms of vasopressor use were reported only if the studies reporting significant outcomes for the same intervention were found.

All of the studies were reviewed by two independent reviewers (A.M. and V.B.). When most studies agreed with the vasopressor-sparing effect, the authors concluded a positive effect. When the results did not meet a consensus, the authors concluded uncertainty, and when most studies were negative, the authors concluded a negative effect.

\subsection{Algorithm and Study Selection}

We included all of the relevant studies found in the Medline database (Pubmed) and Cochrane Library from searches conducted in May 2020 and updated in March 2021, using the following algorithm: "Cardiovascular Agents/therapeutic use" [Mesh Terms] OR "Cardiovascular Agents/administration and dosage" [Mesh Terms] OR "vasoconstrictor agents/administration and dosage" [Mesh Terms] OR "norepinephrine/administration and dosage" [Mesh Terms] OR "Catecholamines/administration and dosage" [Mesh Terms] OR "Vasoconstrictor Agents/therapeutic use" OR "Catecholamines/therapeutic use" [Mesh Terms] OR "norepinephrine/therapeutic use" [MeSH Terms] OR "Shock/therapy" [MeSH Terms] OR "Algorithms" [MeSH Terms]) AND "humans" [MeSH Terms] AND ("adult" [MeSH Terms] OR "aged" [MeSH Terms] OR "middle aged" [MeSH Terms]) AND ("Shock" [MeSH Terms] OR "Multiple Organ Failure" [MeSH Terms] OR ("Lactic Acid/blood" [MeSH Terms] AND ("vasoconstrictor agents/administration and dosage" [Mesh Terms] OR "norepinephrine/administration and dosage" [Mesh Terms] OR "Catecholamines/administration and dosage" [Mesh Terms] OR "Vasoconstrictor Agents/therapeutic use" OR "Catecholamines/therapeutic use" [Mesh Terms] OR "norepinephrine/therapeutic use" [MeSH Terms] "Cardiovascular Agents/therapeutic use" [Mesh Terms] OR "Cardiovascular Agents/administration and dosage" [Mesh Terms])) AND Randomized Controlled Trial [Publication Type]). The search included all publications since 1995.

\section{Results}

Among the 830 studies screened, 143 were included (Figure 1). Forty studies were not reported because the intervention was only negative for the intervention presented. The main reason for vasopressor administration was septic shock $(75 \%) ; 6 \%$ of studies included patients with cardiogenic shock. Other reason for vasopressor administrations were post cardiopulmonary bypass $(3 \%)$, post-operative $(2 \%)$, post cardiac arrest $(1 \%)$, burn $(3 \%)$, hypovolemia $(1 \%)$, distributive shock $(1 \%)$, vasodilatory shock $(2 \%)$, and trauma $(1 \%)$. In $4 \%$ of studies, the causes of shock were multiple. Only four RCTs were specifically related to vasopressor weaning [7,13-15]. Three studies reported therapeutic algorithms and one study reported a pharmacological intervention. 


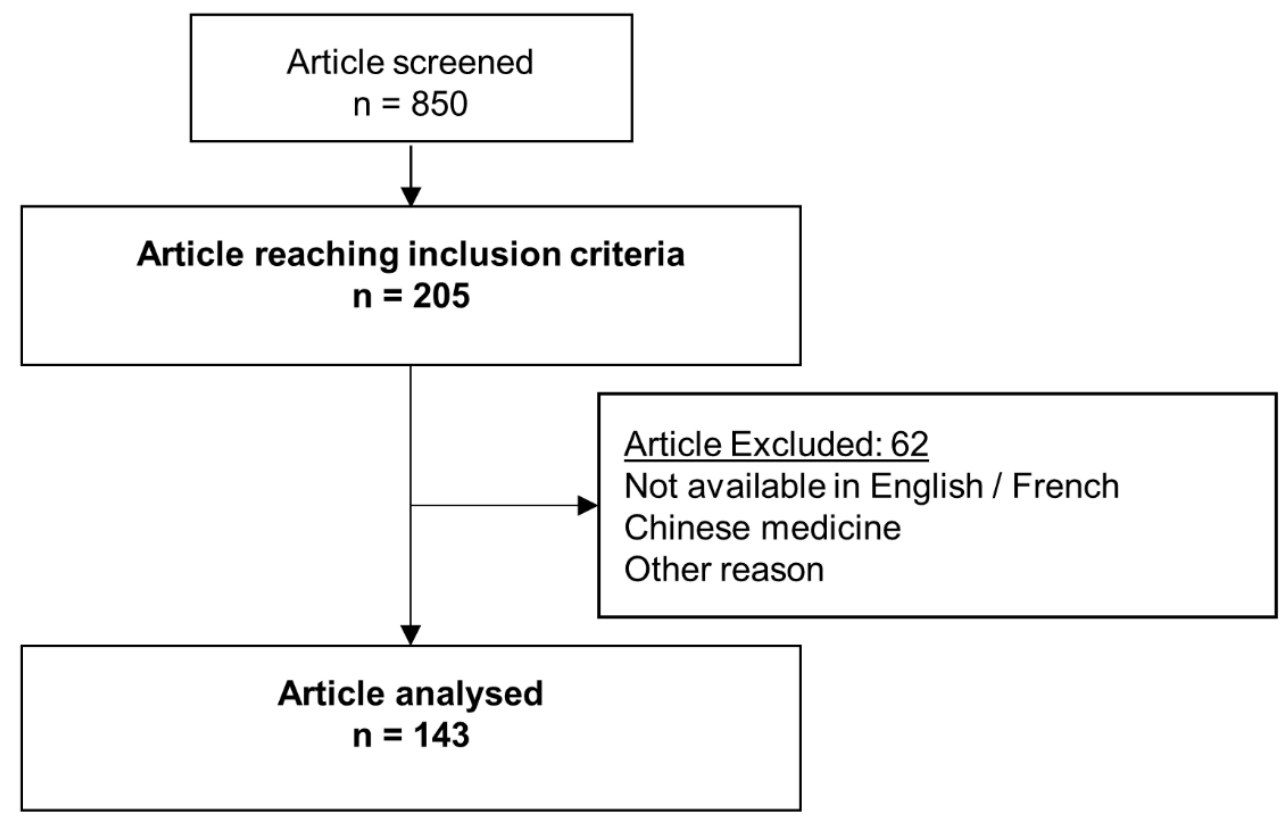

Figure 1. Flow chart study.

\subsection{Pharmacological Interventions}

The main results are summarized in Table 1.

Table 1. Main intervention and proposed use.

\begin{tabular}{|c|c|c|c|c|}
\hline Intervention & References & Outcome Evaluated & Clinical Effect & Proposal \\
\hline \multicolumn{5}{|l|}{$\begin{array}{l}\text { Hemodynamic } \\
\text { management }\end{array}$} \\
\hline $\begin{array}{l}\text { Active, hemodynamic } \\
\text { algorithm }\end{array}$ & {$[7,13]$} & Dose and duration & Positive & Systematic \\
\hline Blood pressure target & {$[16,17]$} & Dose and duration & Positive & $\begin{array}{l}\text { Individualized on organ } \\
\text { perfusion }\end{array}$ \\
\hline $\begin{array}{l}\text { Wean norepinephrine before } \\
\text { vasopressin }\end{array}$ & [14] & Duration & Uncertain & Wean norepinephrine first \\
\hline \multicolumn{5}{|l|}{ Pharmocological } \\
\hline Dopamine & {$[3]$} & Dose and duration & Negative & No \\
\hline Terlipressin & [18-23] & Dose and duration & Negative & No \\
\hline Vasopressin & {$[4,20,24-31]$} & Dose and duration & Uncertain & $\begin{array}{c}\text { Consider if norepinephrine }> \\
0.2 \mu \mathrm{g} / \mathrm{kg} / \mathrm{min}\end{array}$ \\
\hline Angiotensin-2 & {$[32,33]$} & Dose and duration & Uncertain & Mores studies need \\
\hline Glucocorticoids & [34-52] & Dose and duration & Positive & $\begin{array}{l}\text { Systematic if norepinephrine } \\
>0.2 \mu \mathrm{g} / \mathrm{kg} / \mathrm{min}\end{array}$ \\
\hline $\begin{array}{l}\text { Fluid therapy and } \\
\text { hemodynamic goal direct } \\
\text { therapy }\end{array}$ & [53-66] & Dose and duration & Uncertain & Assess preload dependency \\
\hline Colloid & {$[67,68]$} & Dose and duration & Positive & Not recommended \\
\hline Beta-blockers & [69] & Dose & Uncertain & $\begin{array}{l}\text { Selected population with } \\
\text { persistent tachycardia }\end{array}$ \\
\hline Methylene blue & {$[70,71]$} & Dose and duration & Uncertain & Rescue \\
\hline Mineralocorticosteroids & {$[39,72]$} & Duration & Negative & No \\
\hline
\end{tabular}


Table 1. Cont.

\begin{tabular}{|c|c|c|c|c|}
\hline Intervention & References & Outcome Evaluated & Clinical Effect & Proposal \\
\hline$N$-acetyl cysteine & [73-75] & Dose and duration & Uncertain & No \\
\hline Vitamin C & {$[43,44,73,76-78]$} & Dose and duration & Negative & No \\
\hline Oral vasopressor & {$[15,79]$} & Dose and duration & Negative & No \\
\hline \multicolumn{5}{|l|}{ Non-pharmacological } \\
\hline Body temperature & [80-82] & Dose and duration & Positive & Target normothermia \\
\hline High volume hemo-filtration & [83-88] & Dose and duration & Negative & No \\
\hline Adsorption & [89-93] & Dose and duration & Uncertain & No \\
\hline
\end{tabular}

\subsubsection{Vasopressor}

The SOAP (Sepsis Occurrence in Acutely Ill Patients) II study, which compared norepinephrine to dopamine, demonstrated a higher number of vasopressor-free days with norepinephrine [3]. In a small trial, norepinephrine doses were lower when randomized against phenylephrine [94]. Similar vasopressor outcomes were observed with epinephrine compared with norepinephrine $[95,96]$ and with norepinephrine plus dobutamine $[97,98]$. Many RCTs have compared therapeutic strategies by combining a catecholaminergic to a non-catecholaminergic vasopressor. These RCTs mainly demonstrated that adding a non-catecholaminergic vasopressor decreased the catecholamine dose. The non-catecholaminergic vasopressors studied were vasopressin [20,24-29] and its derivatives (terlipressin [18-20,23], selepressin [99]), as well as angiotensin-2 [32]. The effect of vasopressin seems to be dose-dependent [100]. Two small studies did not demonstrate differences in catecholamine administration in patients treated with terlipressin [21] and angiotensin-2 [33]. Vasopressin has also been studied in several large RCTs. The VANCS (Vasopressin Versus Norepinephrine for the Management of Shock After Cardiac Surgery) study demonstrated a shorter duration of vasopressor use [30]. The VANISH (Vasopressin vs. Norepinephrine as Initial Therapy in Septic Shock) and the VASST trial found no difference in vasopressor duration in patients with septic shock [4,31], but in the VASST (Vasopressin and Septic Shock Trial) study, vasopressin was associated with a lower dose of norepinephrine. In 526 patients with septic shock, the terlipressin and norepinephrine duration did not differ [22]. Another study comparing dopamine and terlipressin did not demonstrate any difference in vasopressor-free days [101].

\subsubsection{Adjuvant}

The most studied adjuvant therapy was glucocorticoids [34-42,45-52]. In large RCTs, substitutive corticotherapy consistently decreased the time to shock reversal [38-41]. Patients were mostly included in the early phase of septic shock. One RCT demonstrated an improvement in shock reversal in patients with late septic shock (i.e., $>48$ h) [36]. Hydrocortisone as an adjunctive treatment of vasopressin also decreased the duration of vasopressor administration [42]. Only one trial evaluated mineralocorticoid against a placebo. In this $2 \times 2$ factorial trial, fludrocortisone alone was not associated with more vasopressor-free days than the placebo [72].

Vitamin C has also been the object of several negative RCTs [76-78]. Two RCTs demonstrated a decrease in the time to resolution of shock in patients treated with a combination of thiamine, hydrocortisone, and vitamin C. However, because a combination of several drugs, including hydrocortisone, was used, the effect of vitamin $C$ was not evaluated $[43,44]$.

In patients with septic shock and tachycardia, esmolol decreased the norepinephrine requirements [69]. In 70 patients with multi-organ dysfunction, a heart rate higher than 90 BPM (beats per minute), and a contraindication to beta-blockers, ivabradine administration did not decrease vasopressor use [102]. 
Two small randomized trials evaluating methylene blue demonstrated a decrease in vasopressor use in both septic and post cardiopulmonary bypass vasoplegia [70,71] $\mathrm{N}$-acetyl cysteine has been reported to decrease a composite vaso-inotropic score in burn patients [75]. However, two studies performed in septic shock did not confirm these results $[73,74]$.

Drotrecogin alfa (activated) [103], pyridoxalated hemoglobin polyoxyethylene (PHP) [104,105], nitric oxyide synthase inhibitors [106-108], and monoclonal antibody to human tumor necrosis factor $[109,110]$ have been associated with decreased norepinephrine administration, but these drugs were abandoned for safety reasons (PHP [104] and nitric oxide synthase inhibitor [106]) or lack of efficacy (monoclonal antibody to human tumor necrosis factor [111], and Drotrecogin alfa [103,112,113]).

One RCT study demonstrated a decrease in norepinephrine and dopamine administration with heptaminol [15]. Midodrine is another oral vasoconstrictor frequently administered to reduce the time to norepinephrine weaning. Midodrine has been inconsistently associated with shorter vasopressor administration and ICU length of stay [114-116]. The recent MIDAS (effect of midodrine versus placebo on time to vasopressor discontinuation in patients with persistent hypotension in the intensive care unit) trial reported that midodrine did not reduce time to vasopressor discontinuation in patients with persistent hypotension [79].

\subsection{Fluid Therapy}

During early goal-directed therapy (EGDT), the relationship between the volume of fluid administered and the norepinephrine doses were inconstant [53,54,57-60,62,63]. One RCT evaluating a restrictive fluid strategy did not result in increased doses of vasopressors, despite the higher volumes of administered fluid [61], whereas a second study found no differences in fluid volume and vasopressor use between groups [56]. Fluid titration based on dynamic preload parameters resulted in a similar shock duration, despite a lower fluid intake [64]. In line with this result, two RCTs evaluating a hemodynamic strategy based on cardiac output monitoring did not demonstrate a decrease in vasopressor treatment $[65,66]$. In another trial, PICCO (Pulse Contour Cardiac Output) guided resuscitation was associated with the administration of fewer vasopressors [55]. The CRISTAL-RCT (Colloids Versus Crystalloids for the Resuscitation of the Critically Ill) reported more days alive without vasopressors with colloid use in comparison with crystalloid use [67]. In the ALBIOS (Albumin Italian Outcome Sepsis) study, the administration of albumin decreased both the time to vasopressor or inotropic agent cessation and the fluid balance [68].

\subsection{Body Temperature}

In septic patients, external fever control aiming for 36.5 to $37^{\circ} \mathrm{C}$ decreased the vasopressor requirement [80]. Hypothermia $\left(32-34^{\circ} \mathrm{C}\right)$ was associated with fewer vasopressorfree days [81]. In patients with cardiogenic shock, moderate hypothermia $\left(33^{\circ} \mathrm{C}\right)$ did not decrease vasopressor administration [82].

\subsection{Kidney Replacement Therapy}

In patients with septic shock, the early application of continuous veno-venous filtration resulted in a longer time to shock reversal [117]. Three small studies on high volume hemofiltration $[83,84]$ and cytosorb therapy [89] demonstrated a decrease in vasopressor treatment. Several studies including high volume hemofiltration did not confirm those results [85-88]. Adsorption did not allow for a decrease in norepinephrine administration [90-93]. One study comparing adsorption to high volume hemofiltration did not demonstrate any differences [118].

\section{Discussion}

This review suggests that several pharmacological and non-pharmacological strategies are associated with a decrease in the duration of vasopressor therapy. These strategies 
are as follows. (1) The implementation of a blood pressure objective affects vasopressor duration, but without evidence in terms of mortality. (2) Implementing a weaning strategy decreases the duration of vasopressor treatment and ICU stays. (3) Vasopressin may decrease norepinephrine doses-weaning norepinephrine after vasopressin in case of co-administration seemed to decrease hypotensive episodes. (4) Systemic glucocorticoid administration increased the number of vasopressor-free days. (5) Beta-blockers might decrease norepinephrine doses and duration in selected patients. (6) Targeting normothermia might make it feasible to decrease vasopressor administration. (7) On the contrary, an analysis of the literature demonstrated that EGDT, including fluid therapy, oral vasopressors, vitamin $C$, and renal replacement therapy, are not associated with an increase in vasopressor-free days.

\subsection{Pharmacological Strategies}

Adding a non-catecholaminergic vasopressor to norepinephrine makes is possible to lower its dosage, and the administration of a non-catecholaminergic drug is recommended for patients in refractory shock [5]. Vasopressin deficiency is part of the pathological mechanisms leading to vasoplegia in septic shock [119], and might explain the lower tolerance to vasopressin weaning compared with norepinephrine [14]. However, metaanalysis did not report any differences in mortality or length of stay [120,121]. Angiotensin2 is likely to have similar effects, but has been less studied because it only recently received FDA (Food and Drug Administration) approval. Thus, in a context where vasopressin and norepinephrine are being administered, it seems that norepinephrine should be weaned first $[14,121]$. However, because of its inotropic effect, norepinephrine should be weaned depending on the myocardial contractility.

Glucocorticoids are known to restore vascular responsiveness [122], and can be used to treat corticosteroid insufficiency [123] and block the synthesis of pro-inflammatory cytokines [124]. Substitutive corticotherapy was the most described adjuvant treatment, and it was reported to consistently decrease time to shock reversal. However, the timing of this intervention was not consistent in every trial, and in the most recent surviving sepsis guidelines, glucocorticoids are only advised in refractory shock [5]. One trial specifically focused on late shock reversal demonstrated that low-dose glucocorticoids are beneficial in vasopressor weaning, mainly in patients with sepsis and a high dose of vasopressors (more than $0.20 \mu \mathrm{g} / \mathrm{kg} / \mathrm{min}$ ).

Cardio-selective beta-blockers were demonstrated to lower vasopressor doses in patients with sepsis and tachycardia [69]. This phenomenon was attributed to a decrease in arterial load associated with an improvement in ventriculo-arterial coupling [125]. During weaning, the rate control might improve the ventriculo-arterial coupling [126], suggesting that it could be an interesting therapeutic approach in selected patients.

During hemodynamic resuscitation, fluid therapy does not result in shorter vasopressor treatment, and could even increase vasopressor duration [127]. Thus, it is unlikely that uncontrolled administration of fluids during the optimization and weaning phases would reduce vasopressor duration. Because increasing vasopressors might increase cardiac preload $[128,129]$, in the context of weaning, hypotension might be related to preload reduction. Because removing fluids is another cornerstone of de-resuscitation [130], we believe that preload status should be carefully evaluated in patients with hypotension attributed to vasopressor weaning.

\subsection{Hemodynamic Strategies}

In practice, norepinephrine weaning is implemented empirically: when the arterial pressure is consistently above the given objective, the dose of norepinephrine is decreased until discontinuation. Because vasopressors act on several pathological mechanisms involved in blood pressure (preload [128], inotropism [10], and vascular resistance [10]), arterial hypotension following a decrease in vasopressor dose can have multiple causes, and several studies demonstrated that arterial dynamic elastance $\left(\mathrm{E}_{\mathrm{Adyn}}=\right.$ respiratory pulse 
pressure variation/respiratory stroke volume variation), which may reflect ventriculoarterial coupling and vasomotor tone, can predict the pressure response to norepinephrine weaning [131]. An $\mathrm{E}_{\mathrm{Adyn}}$-based algorithm decreased norepinephrine administration [7], and the automation of the weaning process by a controller responding to "fuzzy logic" made it possible to reduce the weaning time [13]. Because targeting the lower blood pressure target is associated with faster vasopressor discontinuation, it is clear that setting the right pressure target is an important decision. During acute circulatory failure, a minimal threshold for blood pressure is often set in order to ensure organ perfusion. In a recent study, setting a low blood pressure target ( 60 to $65 \mathrm{mmHg}$ ) in patients older than 65 years old with vasodilatory hypotension resulted in lower exposure to vasopressors, without a significant difference in morbidity or mortality [132]. This trial further suggested that lower blood pressure might be targeted in a selected resuscitated population, and that a lower objective might result in lower vasopressor exposure without adverse events. Nevertheless, blood pressure targets should be individualized to ensure organ perfusion [133].

\subsection{Proposed Algorithm}

Because vasopressors are associated with adverse effects [134], vasopressor-sparing strategies have emerged [135]. Vasopressor sparing strategies aim to reduce vasopressor exposure and their side effects [7]. Vasopressor administration is part of the continuum from initial resuscitation to shock reversal. As for fluid therapy, the management of vasopressors can be divided into several phases: an initial resuscitation phase with the objective of obtaining the target blood pressure to restore tissue perfusion as quickly as possible, a stabilization phase, and a weaning phase (Figure 2). When the patient is stabilized, active management, including pharmacological therapies and hemodynamic strategies, may be introduced to decrease the time to vasopressor discontinuation. Hemodynamic stability can be defined as a blood pressure variation of less than $10 \%$ without changing the vasopressor dose, and with an improvement in tissue perfusion (capillary refill time, hyperlactatemia, diuresis, and venous oxygen saturation) [7]. When blood pressure is controlled, the cardiac and vascular properties are gradually restored and the withdrawal of vasopressor drugs can be initiated (Figure 2). As the pathological process may not be symmetrical during acute circulatory failure and recovery, and as catecholamine administration leads to the down-regulation of adrenergic receptors [30], it is unlikely that vasopressor withdrawal is a parallel process to the initial resuscitation phase.

\section{Vasopressor therapy principles}

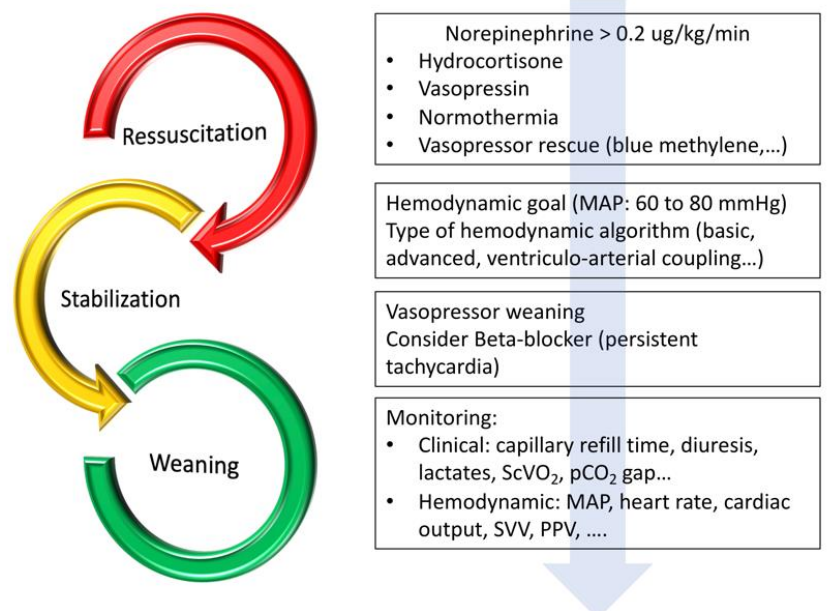

Figure 2. Principles of vasopressor treatment. $\mathrm{MAP}$ - mean arterial pressure; $\mathrm{ScVO}_{2}$ - central venous oxygen saturation; $\mathrm{pCO}_{2}$ Gap-difference between partial pressure of $\mathrm{CO}_{2}$ in venous blood and arterial blood; SVV—-stroke volume variation; PPV—-pulse pressure variation. 
Optimization and weaning should be part of a protocolized process (Figure 2). Firstly, a blood pressure target aiming to optimize organ perfusion should be defined by taking into account that a lower blood pressure objective may be possible. Secondly, physicians should consider the early use of intravenous hydrocortisone, non-catecholaminergic vasopressors (vasopressin and blue methylene), and maintaining normothermia. In selected patients with persistent tachycardia, beta-blocker therapy should be considered. Thirdly, when hemodynamic stability is obtained, active weaning should be initiated following a hemodynamic algorithm (see below). Because of their action on preload, inotropism, and arterial load, vasopressor withdrawal should be adapted to the patient's haemodynamic profile, similarly to therapeutic escalation in the acute phase.

Several approaches can be followed depending on the type of monitoring (Figure 3). Basic management based on continuous measurement of blood pressure is probably the most commonly used approach. In the case of poor tolerance, the different causes listed above should be considered and eliminated in the order of the following frequency: preload, arterial load, and inotropism. A hemodynamic approach based on the analysis of ventriculoarterial coupling and/or $\mathrm{E}_{\mathrm{Adyn}}$ may be suitable [131,136-139]. Studies have demonstrated that $\mathrm{E}_{\mathrm{Adyn}}$ and the analysis of ventriculo-arterial coupling are able to predict the effects of norepinephrine on stroke volume and blood pressure $[7,140]$. Arterial elastance $\left(\mathrm{E}_{\mathrm{A}}\right)$ is an index of arterial load [141] that integrates the main components of arterial load (i.e., total peripheral resistance, total net arterial compliance, characteristic impedance, and systolic and diastolic time intervals). $\mathrm{E}_{\mathrm{A}}$ can be estimated by using the equation $\mathrm{E}_{\mathrm{A}}=$ mean arterial pressure/stroke volume $(\mathrm{mmHg} / \mathrm{mL})$ [142]. Left ventricular endsystolic elastance $\left(\mathrm{E}_{\mathrm{V}}\right)$ is an indicator of cardiac function [143], and might be extrapolated by using the non-invasive single beat method described by Chen et al. [144]. Ventriculoarterial coupling is the ratio of $\mathrm{E}_{\mathrm{A}}$ to $\mathrm{E}_{\mathrm{V}}$, and it is an indicator of the balance between cardiac effort and arterial load. When the left ventricle and the vascular system are coupled, this ratio is around 1 [145]. Such approaches are made possible by the use of echocardiography or a continuous hemodynamic monitoring system [136-139]. In the future, physicians could consider using automation and artificial intelligence to guide the weaning process $[13,146]$. A recent study published in the JAMA showed that the use of this index with a therapeutic management decision algorithm reduces hypotension time [146].

A

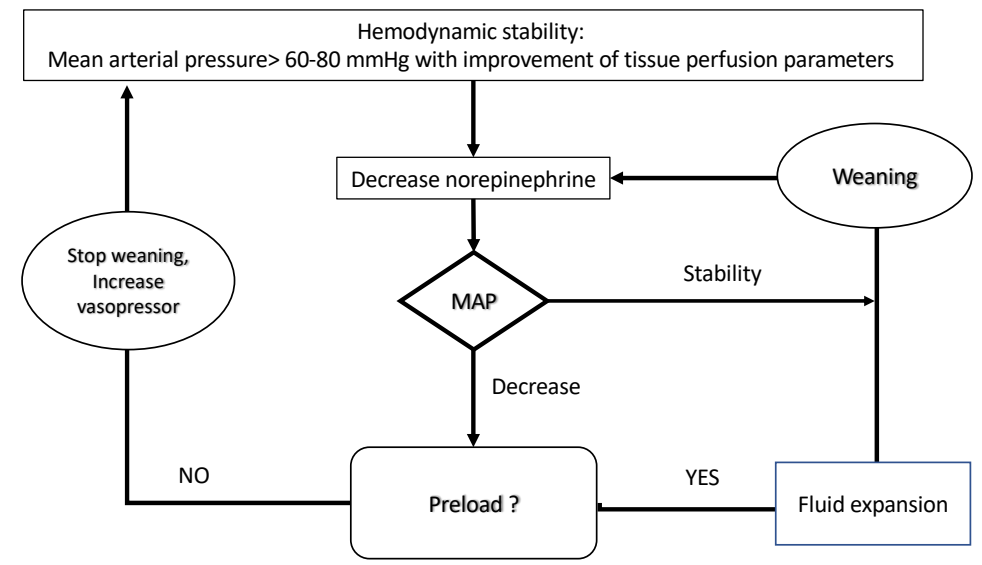

Figure 3. Cont. 
B

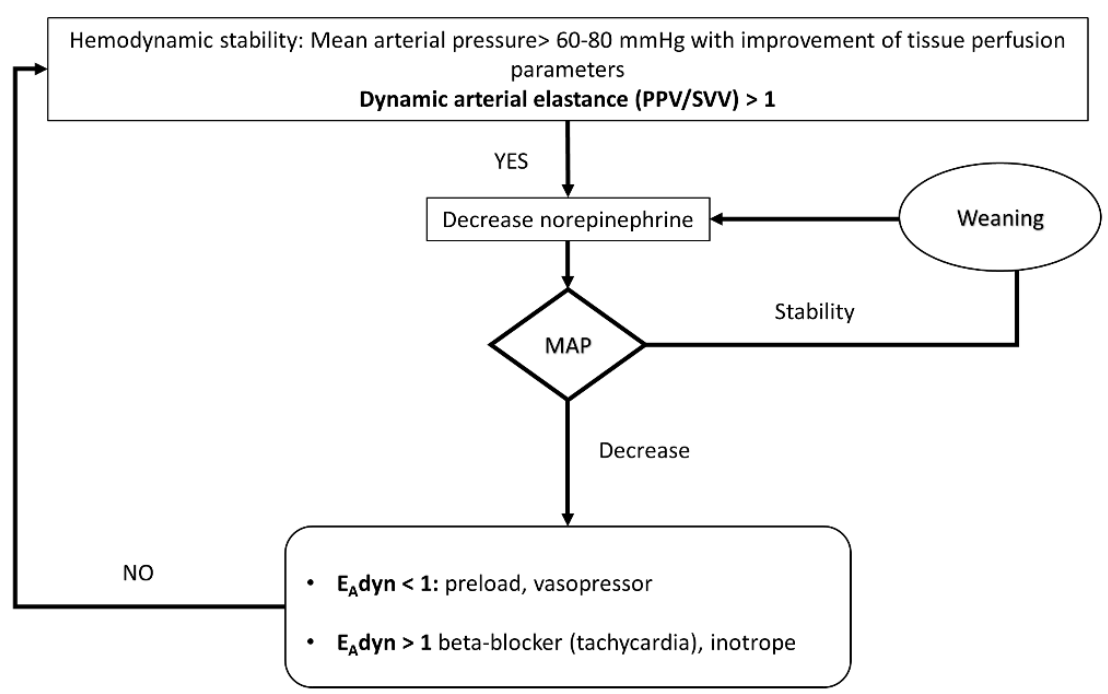

C

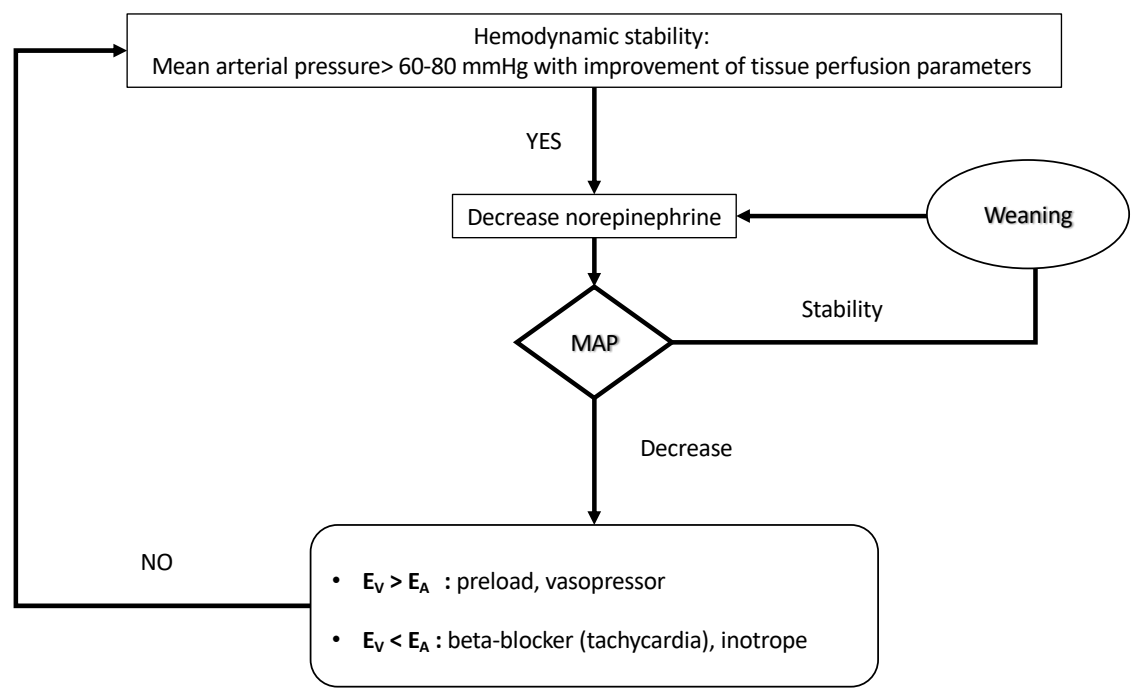

Figure 3. Algorithm proposed for vasopressor weaning. (A) Basic algorithm. (B) Advanced algorithm based on dynamic arterial elastance analysis. (C) Advanced algorithm based on ventriculo-arterial coupling analysis. $\mathrm{E}_{\mathrm{Adyn}}$-dynamic arterial elastance; PPV—pulse pressure variation; SVV—stroke volume variation; $\mathrm{E}_{\mathrm{V}}$ - ventricular elastance; $\mathrm{E}_{\mathrm{A}}$ - arterial elastance.

Several limitations can be discussed. We can question the clinical benefit of a vasopressor sparing strategy. There is no direct evidence that reducing pressor "stress" decreases mortality. However, studies have demonstrated that decreasing the duration of vasopressor use is associated with a decrease of ICU length of stays and morbidity [7]. Moreover, a pooled analysis of two studies suggested that increased exposure to vasopressor increased the risk of death [6]. Because vasopressor adverse effect are largely documented, sparing vasopressor and/or catecholamine is a topic of growing interest [135,147]. Most included studies were performed in sepsis $(75 \%)$ or postoperative vasoplegic shock, thus limiting the extrapolation of our scoping review to these types of shock. According to the PRISMA-scr guidelines, the critical appraisal of the included sources of evidence was not mandatory. Be- 
cause of the study design, the clinical benefit of the reviewed interventions was determined by the authors, and the criteria may be subjective.

\section{Conclusions}

There are a few published RCTs focused specifically on sparing strategies. In patients with shock, several pharmacological strategies, such as hydrocortisone, can be safely used to optimize vasopressor treatment. In addition, it appears that optimized patient management using hemodynamic guidelines could be associated with more vasopressorfree days and shorter ICU stays.

Author Contributions: Conceptualization, P.-G.G., M.N. and B.B.; methodology, P.-G.G. and M.N.; formal analysis, P.-G.G., A.M., V.B., P.V., L.B., E.S. and M.N.; writing-original draft preparation, P.-G.G. and M.N. All authors have read and agreed to the published version of the manuscript.

Funding: This research received no external funding.

Institutional Review Board Statement: Not applicable.

Informed Consent Statement: Not applicable.

Data Availability Statement: The data presented in the study are available upon request from the corresponding author.

Acknowledgments: Thank you to Suzanne Rankin for proofreading and reviewing the English manuscript.

Conflicts of Interest: The authors declare no conflict of interest.

\section{References}

1. Landry, D.W.; Oliver, J.A. The Pathogenesis of Vasodilatory Shock. N. Engl. J. Med. 2001, 345, 588-595. [CrossRef]

2. Sakr, Y.; Reinhart, K.; Vincent, J.-L.; Sprung, C.L.; Moreno, R.; Ranieri, V.M.; De Backer, D.; Payen, D. Does dopamine administration in shock influence outcome? Results of the Sepsis Occurrence in Acutely Ill Patients (SOAP) Study*. Crit. Care Med. 2006, 34, 589-597. [CrossRef]

3. De Backer, D.; Biston, P.; Devriendt, J.; Madl, C.; Chochrad, D.; Aldecoa, C.; Brasseur, A.; Defrance, P.; Gottignies, P.; Vincent, J.-L. Comparison of Dopamine and Norepinephrine in the Treatment of Shock. N. Engl. J. Med. 2010, 362, 779-789. [CrossRef]

4. Russell, J.A.; Walley, K.R.; Singer, J.; Gordon, A.C.; Hébert, P.C.; Cooper, D.J.; Holmes, C.L.; Mehta, S.; Granton, J.T.; Storms, M.M.; et al. Vasopressin versus Norepinephrine Infusion in Patients with Septic Shock. N. Engl. J. Med. 2008, 358, 877-887. [CrossRef] [PubMed]

5. $\quad$ Rhodes, A.; Evans, L.E.; Alhazzani, W.; Levy, M.M.; Antonelli, M.; Ferrer, R.; Kumar, A.; Sevransky, J.E.; Sprung, C.L.; Nunnally, M.E.; et al. Surviving Sepsis Campaign: International Guidelines for Management of Sepsis and Septic Shock: 2016. Intensive Care Med. 2017, 43, 304-377. [CrossRef]

6. $\quad$ Lamontagne, F.; Day, A.G.; Meade, M.O.; Cook, D.J.; Guyatt, G.H.; Hylands, M.; Radermacher, P.; Chrétien, J.M.; Beaudoin, N.; Hébert, P.; et al. Pooled analysis of higher versus lower blood pressure targets for vasopressor therapy septic and vasodilatory shock. Intensive Care Med. 2018, 44, 12-21. [CrossRef] [PubMed]

7. Guinot, P.-G.; Abou-Arab, O.; Guilbart, M.; Bar, S.; Zogheib, E.; Daher, M.; Besserve, P.; Nader, J.; Caus, T.; Kamel, S.; et al. Monitoring dynamic arterial elastance as a means of decreasing the duration of norepinephrine treatment in vasoplegic syndrome following cardiac surgery: A prospective, randomized trial. Intensive Care Med. 2017, 43, 643-651. [CrossRef] [PubMed]

8. Hollenberg, S.M. Concise Clinical Review Vasoactive Drugs in Circulatory Shock. Am. J. Respir. Crit. Care Med. 2011, 183, 847-855. [CrossRef]

9. Bangash, M.N.; Kong, M.L.; Pearse, R.M. Use of inotropes and vasopressor agents in critically ill patients. Br. J. Pharmacol. 2012, 165, 2015-2033. [CrossRef] [PubMed]

10. Russell, J.A. Vasopressor therapy in critically ill patients with shock. Intensive Care Med. 2019, 45, 1503-1517. [CrossRef]

11. Russell, J.A.; Gordon, A.C.; Williams, M.D.; Boyd, J.H.; Walley, K.R.; Kissoon, N. Vasopressor Therapy in the Intensive Care Unit. Semin. Respir. Crit. Care Med. 2021, 42, 59-77. [PubMed]

12. Tricco, A.C.; Lillie, E.; Zarin, W.; O’Brien, K.K.; Colquhoun, H.; Levac, D.; Moher, D.; Peters, M.D.J.; Horsley, T.; Weeks, L.; et al. PRISMA extension for scoping reviews (PRISMA-ScR): Checklist and explanation. Ann. Intern. Med. 2018, 169, 467-473. [CrossRef] [PubMed]

13. Merouani, M.; Guignard, B.; Vincent, F.; Borron, S.W.; Karoubi, P.; Fosse, J.-P.; Cohen, Y.; Clec'h, C.; Vicaut, E.; Marbeuf-Gueye, C.; et al. Norepinephrine weaning in septic shock patients by closed loop control based on fuzzy logic. Crit. Care 2008, $12, \mathrm{R} 155$. [CrossRef] 
14. Jeon, K.; Song, J.-U.; Chung, C.R.; Yang, J.H.; Suh, G.Y. Incidence of hypotension according to the discontinuation order of vasopressors in the management of septic shock: A prospective randomized trial (DOVSS). Crit. Care 2018, 22, 131. [CrossRef] [PubMed]

15. Bahloul, M.; Chaari, A.; Mbarek, M.N.B.; Kallel, H.; Bouaziz, M. Use of Heptaminol Hydrochloride for Catecholamine Weaning in Septic Shock. Am. J. Ther. 2012, 19, e8-e17. [CrossRef] [PubMed]

16. Asfar, P.; Meziani, F.; Hamel, J.-F.; Grelon, F.; Megarbane, B.; Anguel, N.; Mira, J.-P.; Dequin, P.-F.; Gergaud, S.; Weiss, N.; et al. High versus Low Blood-Pressure Target in Patients with Septic Shock. N. Engl. J. Med. 2014, 17, 1583-1593. [CrossRef] [PubMed]

17. Lamontagne, F.; Meade, M.O.; Hébert, P.C.; Asfar, P.; Lauzier, F.; Seely, A.J.E.; Day, A.G.; Mehta, S.; Muscedere, J.; Bagshaw, S.M.; et al. Higher versus lower blood pressure targets for vasopressor therapy in shock: A multicentre pilot randomized controlled trial. Intensive Care Med. 2016, 42, 1-9. [CrossRef] [PubMed]

18. Morelli, A.; Ertmer, C.; Rehberg, S.; Lange, M.; Orecchioni, A.; Cecchini, V.; Bachetoni, A.; D’Alessandro, M.; Van Aken, H.; Pietropaoli, P.; et al. Continuous terlipressin versus vasopressin infusion in septic shock (TERLIVAP): A randomized, controlled pilot study. Crit. Care 2009, 13, R130. [CrossRef]

19. Choudhury, A.; Kedarisetty, C.K.; Vashishtha, C.; Saini, D.; Kumar, S.; Maiwall, R.; Sharma, M.K.; Bhadoria, A.S.; Kumar, G.; Joshi, Y.K.; et al. A randomized trial comparing terlipressin and noradrenaline in patients with cirrhosis and septic shock. Liver Int. 2017, 37, 552-561. [CrossRef]

20. Morelli, A.; Donati, A.; Ertmer, C.; Rehberg, S.; Kampmeier, T.; Orecchioni, A.; Di Russo, A.; D’Egidio, A.; Landoni, G.; Lombrano, M.R.; et al. Effects of vasopressinergic receptor agonists on sublingual microcirculation in norepinephrine-dependent septic shock. Crit. Care 2011, 15, 1-10. [CrossRef]

21. Svoboda, P.; Scheer, P.; Kantorová, I.; Doubek, J.; Dudra, J.; Radvan, M.; Radvanova, J. Terlipressin in the treatment of late phase catecholamine-resistant septic shock. Hepatogastroenterology 2012, 59, 1043-1047.

22. Liu, Z.M.; Chen, J.; Kou, Q.; Lin, Q.; Huang, X.; Tang, Z.; Kang, Y.; Li, K.; Zhou, L.; Song, Q.; et al. Terlipressin versus norepinephrine as infusion in patients with septic shock: A multicentre, randomised, double-blinded trial. Intensive Care Med. 2018, 44, 1816-1825. [CrossRef] [PubMed]

23. Morelli, A.; Ertmer, C.; Lange, M.; Dü Nser, M.; Rehberg, S.; Van Aken, H.; Pietropaoli, P.; Westphal, M. Effects of short-term simultaneous infusion of dobutamine and terlipressin in patients with septic shock: The DOBUPRESS study †. Br. J. Anaesth. 2008, 100, 494-503. [CrossRef] [PubMed]

24. Dünser, M.W.; Mayr, A.J.; Ulmer, H.; Knotzer, H.; Sumann, G.; Pajk, W.; Friesenecker, B.; Hasibeder, W.R. Arginine vasopressin in advanced vasodilatory shock: A prospective, randomized, controlled study. Circulation 2003, 107, 2313-2319. [CrossRef]

25. Luckner, G.; Dünser, M.W.; Stadlbauer, K.H.; Mayr, V.D.; Jochberger, S.; Wenzel, V.; Ulmer, H.; Pajk, W.; Hasibeder, W.R.; Friesenecker, B.; et al. Cutaneous vascular reactivity and flow motion response to vasopressin in advanced vasodilatory shock and severe postoperative multiple organ dysfunction syndrome. Crit. Care 2006, 10, R40. [CrossRef]

26. Lauzier, F.; Lévy, B.; Lamarre, P.; Lesur, O. Vasopressin or norepinephrine in early hyperdynamic septic shock: A randomized clinical trial. Intensive Care Med. 2006, 32, 1782-1789. [CrossRef] [PubMed]

27. Mojtahedzadeh, M.; Barzegar, E.; Ahmadi, A.; Mousavi, S.; Nouri, M.; Mojtahedzadeh, M. The Therapeutic Role of Vasopressin on Improving lactate Clearance During and After Vasogenic Shock: Microcirculation, Is It The Black Box? Acta Med. Iran. 2016, 54, 15-23. Available online: https:/ /acta.tums.ac.ir/index.php/acta/article/view/5384 (accessed on 17 July 2020).

28. Argenziano, M.; Choudhri, A.; Oz, M.C.; Rose, E.A.; Smith, C.R.; Landry, D.W. A prospective randomized trial of arginine vasopressin in the treatment of vasodilatory shock after left ventricular assist device placement. Circulation 1997, 96, II-286. Available online: https:/ / europepmc.org/article/med/9386112 (accessed on 17 July 2020).

29. Patel, B.M.; Chittock, D.R.; Russell, J.A.; Walley, K.R. Beneficial effects of short-term vasopressin infusion during severe septic shock. Anesthesiology 2002, 96, 576-582. [CrossRef]

30. Hajjar, L.A.; Vincent, J.L.; Barbosa Gomes Galas, F.R.; Rhodes, A.; Landoni, G.; Osawa, E.A.; Melo, R.R.; Sundin, M.R.; Grande, S.M.; Gaiotto, F.A.; et al. Vasopressin versus Norepinephrine in Patients with Vasoplegic Shock after Cardiac Surgery. Anesthesiology 2017, 126, 85-93. [CrossRef]

31. Gordon, A.C.; Mason, A.J.; Thirunavukkarasu, N.; Perkins, G.D.; Cecconi, M.; Cepkova, M.; Pogson, D.G.; Aya, H.D.; Anjum, A.; Frazier, G.J.; et al. Effect of Early Vasopressin vs Norepinephrine on Kidney Failure in Patients With Septic Shock. JAMA 2016, 316, 509. [CrossRef] [PubMed]

32. Khanna, A.; English, S.W.; Wang, X.S.; Ham, K.; Tumlin, J.; Szerlip, H.; Busse, L.W.; Altaweel, L.; Albertson, T.E.; Mackey, C.; et al. Angiotensin II for the Treatment of Vasodilatory Shock. N. Engl. J. Med. 2017, 377, 419-430. [CrossRef] [PubMed]

33. Chawla, L.S.; Busse, L.; Brasha-Mitchell, E.; Davison, D.; Honiq, J.; Alotaibi, Z.; Seneff, M.G. Intravenous angiotensin II for the treatment of high-output shock (ATHOS trial): A pilot study. Crit. Care 2014, 18, 534. [CrossRef]

34. Lv, Q.Q.; Gu, X.H.; Chen, Q.H.; Yu, J.Q.; Zheng, R.Q. Early initiation of low-dose hydrocortisone treatment for septic shock in adults: A randomized clinical trial. Am. J. Emerg. Med. 2017, 35, 1810-1814. [CrossRef]

35. Hyvernat, H.; Barel, R.; Gentilhomme, A.; Césari-Giordani, J.F.; Freche, A.; Kaidomar, M.; Goubaux, B.; Pradier, C.; Dellamonica, J.; Bernardin, G. Effects of increasing hydrocortisone to 300mgper day in the treatment of septic shock: A pilot study. Shock 2016, 46, 498-505. [CrossRef] [PubMed]

36. Bollaert, P.E.; Charpentier, C.; Levy, B.; Debouverie, M.; Audibert, G.; Larcan, A. Reversal of late septic shock with supraphysiologic doses of hydrocortisone. Crit. Care Med. 1998, 26, 645-650. [CrossRef] [PubMed] 
37. Cicarelli, D.D.; Vieira, J.E.; Benseñor, F.E.M. Early dexamethasone treatment for septic shock patients: A prospective randomized clinical trial. Sao Paulo Med. J. 2007, 125, 237-241. [CrossRef]

38. Sprung, C.L.; Annane, D.; Keh, D.; Moreno, R.; Singer, M.; Freivogel, K.; Weiss, Y.G.; Benbenishty, J.; Kalenka, A.; Forst, H.; et al. Hydrocortisone Therapy for Patients with Septic Shock. N. Engl. J. Med. 2008, 358, 111-124. [CrossRef]

39. Annane, D.; Renault, A.; Brun-Buisson, C.; Megarbane, B.; Quenot, J.-P.; Siami, S.; Cariou, A.; Forceville, X.; Schwebel, C.; Martin, C.; et al. Hydrocortisone plus Fludrocortisone for Adults with Septic Shock. N. Engl. J. Med. 2018, 378, 809-818. [CrossRef]

40. Venkatesh, B.; Finfer, S.; Cohen, J.; Rajbhandari, D.; Arabi, Y.; Bellomo, R.; Billot, L.; Correa, M.; Glass, P.; Harward, M.; et al. Adjunctive Glucocorticoid Therapy in Patients with Septic Shock. N. Engl. J. Med. 2018, 378, 797-808. [CrossRef]

41. Annane, D.; Sébille, V.; Charpentier, C.; Bollaert, P.-E.; François, B.; Korach, J.-M.; Capellier, G.; Cohen, Y.; Azoulay, E.; Troché, G.; et al. Effect of Treatment With Low Doses of Hydrocortisone and Fludrocortisone on Mortality in Patients With Septic Shock. JAMA 2002, 288, 862. [CrossRef]

42. Gordon, A.C.; Mason, A.J.; Perkins, G.D.; Stotz, M.; Terblanche, M.; Ashby, D.; Brett, S.J. The Interaction of Vasopressin and Corticosteroids in Septic Shock. Crit. Care Med. 2014, 42, 1325-1333. [CrossRef]

43. Iglesias, J.; Vassallo, A.V.; Patel, V.V.; Sullivan, J.B.; Cavanaugh, J.; Elbaga, Y. Outcomes of Metabolic Resuscitation Using Ascorbic Acid, Thiamine, and Glucocorticoids in the Early Treatment of Sepsis: The ORANGES Trial. Chest 2020, 158, 164-173. [CrossRef] [PubMed]

44. Moskowitz, A.; Huang, D.T.; Hou, P.C.; Gong, J.; Doshi, P.B.; Grossestreuer, A.V.; Andersen, L.W.; Ngo, L.; Sherwin, R.L.; Berg, K.M.; et al. Effect of Ascorbic Acid, Corticosteroids, and Thiamine on Organ Injury in Septic Shock: The ACTS Randomized Clinical Trial. JAMA 2020, 324, 642-650. [CrossRef] [PubMed]

45. Donnino, M.W.; Andersen, L.W.; Berg, K.M.; Chase, M.; Sherwin, R.; Smithline, H.; Carney, E.; Ngo, L.; Patel, P.V.; Liu, X.; et al. Corticosteroid therapy in refractory shock following cardiac arrest: A randomized, double-blind, placebo-controlled, trial. Crit. Care 2016, 20, 82. [CrossRef] [PubMed]

46. Oppert, M.; Reinicke, A.; Gräf, K.J.; Barckow, D.; Frei, U.; Eckardt, K.U. Plasma cortisol levels before and during "low-dose" hydrocortisone therapy and their relationship to hemodynamic improvement in patients with septic shock. Intensive Care Med. 2000, 26, 1747-1755. [CrossRef]

47. Arabi, Y.M.; Aljumah, A.; Dabbagh, O.; Tamim, H.M.; Rishu, A.H.; Al-Abdulkareem, A.; Al Knawy, B.; Hajeer, A.H.; Tamimi, W.; Cherfan, A. Low-dose hydrocortisone in patients with cirrhosis and septic shock: A randomized controlled trial. CMAJ 2010, 182, 1971-1977. [CrossRef] [PubMed]

48. Kaufmann, I.; Briegel, J.; Schliephake, F.; Hoelzl, A.; Chouker, A.; Hummel, T.; Schelling, G.; Thiel, M. Stress doses of hydrocortisone in septic shock: Beneficial effects on opsonization-dependent neutrophil functions. Intensive Care Med. 2008, 34, 344-349. [CrossRef] [PubMed]

49. Ngaosuwan, K.; Ounchokdee, K.; Chalermchai, T. Clinical Outcomes of Minimized Hydrocortisone Dosage of $100 \mathrm{Mg} / \mathrm{Day}$ on Lower Occurrence of Hyperglycemia in Septic Shock Patients. Shock 2018, 50, 280-285. [CrossRef]

50. Oppert, M.; Schindler, R.; Husung, C.; Offermann, K.; Gräf, K.-J.; Boenisch, O.; Barckow, D.; Frei, U.; Eckardt, K.-U. Low-dose hydrocortisone improves shock reversal and reduces cytokine levels in early hyperdynamic septic shock*. Crit. Care Med. 2005, 33, 2457-2464. [CrossRef]

51. Mussack, T.; Briegel, J.; Schelling, G.; Jochum, M. Hemofiltrastion does not influence early S-100B serum levels in septic shock patients receiving stress doses of hydrocortisone or placebo. Eur. J. Med. Res. 2005, 10, 11-17.

52. Briegel, J.; Forst, H.; Haller, M.; Schelling, G.; Kilger, E.; Kuprat, G.; Hemmer, B.; Hummel, T.; Lenhart, A.; Heyduck, M.; et al. Stress doses of hydrocortisone reverse hyperdynamic septic shock: A prospective, randomized, double-blind, single-center study. Crit. Care Med. 1999, 27, 723-732. [CrossRef] [PubMed]

53. Rivers, E.; Nguyen, B.; Havstad, S.; Ressler, J.; Muzzin, A.; Knoblich, B.; Peterson, E.; Tomlanovich, M. Early Goal-Directed Therapy in the Treatment of Severe Sepsis and Septic Shock. N. Engl. J. Med. 2001, 345, 1368-1377. [CrossRef] [PubMed]

54. Lin, S.-M.; Huang, C.-D.; Lin, H.-C.; Liu, C.-Y.; Wang, C.-H.; Kuo, H.-P. A modified goal-directed protocol improves clinical outcomes in intensive care unit patients with septic shock. Shock 2006, 26, 551-557. [CrossRef] [PubMed]

55. Lu, N.F.; Zheng, R.Q.; Lin, H.; Shao, J.; Yu, J.Q.; Yang, D.G. Improved sepsis bundles in the treatment of septic shock: A prospective clinical study. Am. J. Emerg. Med. 2015, 33, 1045-1049. [CrossRef]

56. Chen, C.; Kollef, M.H. Targeted fluid minimization following initial resuscitation in septic shock a pilot study. Chest 2015, 148, 1462-1469. [CrossRef]

57. Gomersall, C.D.; Joynt, G.M.; Freebairn, R.C.; Hung, V.; Buckley, T.A.; Oh, T.E. Resuscitation of critically ill patients based on the results of gastric tonometry: A prospective, randomized, controlled trial. Crit. Care Med. 2000, 28, 607-614. [CrossRef]

58. Jones, A.E.; Shapiro, N.I.; Trzeciak, S.; Arnold, R.C.; Claremont, H.A.; Kline, J.A. Lactate clearance vs central venous oxygen saturation as goals of early sepsis therapy: A randomized clinical trial. JAMA J. Am. Med. Assoc. 2010, 303, 739-746. [CrossRef]

59. Yu, J.; Zheng, R.; Lin, H.; Chen, Q.; Shao, J.; Wang, D. Global end-diastolic volume index vs CVP goal-directed fluid resuscitation for COPD patients with septic shock: A randomized controlled trial. Am. J. Emerg. Med. 2017, 35, 101-105. [CrossRef] [PubMed]

60. Mouncey, P.R.; Osborn, T.M.; Power, G.S.; Harrison, D.A.; Sadique, M.Z.; Grieve, R.D.; Jahan, R.; Harvey, S.E.; Bell, D.; Bion, J.F.; et al. Trial of Early, Goal-Directed Resuscitation for Septic Shock. N. Engl. J. Med. 2015, 372, 1301-1311. [CrossRef]

61. Corl, K.A.; Prodromou, M.; Merchant, R.C.; Gareen, I.; Marks, S.; Banerjee, D.; Amass, T.; Abbasi, A.; Delcompare, C.; Palmisciano, A.; et al. The Restrictive IV Fluid Trial in Severe Sepsis and Septic Shock (RIFTS). Crit. Care Med. 2019, 47, 951-959. [CrossRef] 
62. Yealy, D.M.; Kellum, J.A.; Huang, D.T.; Barnato, A.E.; Weissfeld, L.A.; Pike, F.; Terndrup, T.; Wang, H.E.; Hou, P.C.; LoVecchio, F.; et al. A Randomized Trial of Protocol-Based Care for Early Septic Shock. N. Engl. J. Med. 2014, 370, 1683-1693.

63. Peake, S.L.; Delaney, A.; Bailey, M.; Bellomo, R.; Cameron, P.A.; Cooper, D.J.; Higgins, A.M.; Holdgate, A.; Howe, B.D.; Webb, S.A.R.; et al. Goal-Directed Resuscitation for Patients with Early Septic Shock. N. Engl. J. Med. 2014, 371, $1496-1506$.

64. Richard, J.C.; Bayle, F.; Bourdin, G.; Leray, V.; Debord, S.; Delannoy, B.; Stoian, A.C.; Wallet, F.; Yonis, H.; Guerin, C. Preload dependence indices to titrate volume expansion during septic shock: A randomized controlled trial. Crit. Care 2015, 19, 5. [CrossRef]

65. Zhang, Z.; Ni, H.; Qian, Z. Effectiveness of treatment based on PiCCO parameters in critically ill patients with septic shock and/or acute respiratory distress syndrome: A randomized controlled trial. Intensive Care Med. 2015, 41, 444-451. [CrossRef]

66. Tokarik, M.; Sjöberg, F.; Balik, M.; Pafcuga, I.; Broz, L. Fluid therapy lidco controlled trial - Optimization of volume resuscitation of extensively burned patients through noninvasive continuous real-time hemodynamic monitoring LiDCO. J. Burn. Care Res. 2013, 34, 537-542. [CrossRef]

67. Annane, D.; Siami, S.; Jaber, S.; Martin, C.; Elatrous, S.; Descorps Declère, A.; Charles Preiser, J.; Outin, H.; Troché, G.; Charpentier, C.; et al. Effects of Fluid Resuscitation With Colloids vs Crystalloids on Mortality in Critically Ill Patients Presenting With Hypovolemic Shock The CRISTAL Randomized Trial. JAMA 2013, 310, 1809-1817. [CrossRef] [PubMed]

68. Caironi, P.; Tognoni, G.; Masson, S.; Fumagalli, R.; Pesenti, A.; Romero, M.; Fanizza, C.; Caspani, L.; Faenza, S.; Grasselli, G.; et al. Albumin Replacement in Patients with Severe Sepsis or Septic Shock. N. Engl. J. Med. 2014, 370, 1412-1421. [CrossRef] [PubMed]

69. Morelli, A.; Ertmer, C.; Westphal, M.; Rehberg, S.; Kampmeier, T.; Ligges, S.; Orecchioni, A.; D’Egidio, A.; D’Ippoliti, F.; Raffone, C.; et al. Effect of heart rate control with esmolol on hemodynamic and clinical outcomes in patients with septic shock: A randomized clinical trial. JAMA J. Am. Med. Assoc. 2013, 310, 1683-1691. [CrossRef] [PubMed]

70. Kirov, M.Y.; Evgenov, O.V.; Evgenov, N.V.; Egorina, E.M.; Sovershaev, M.A.; Sveinbjørnsson, B.; Nedashkovsky, E.V.; Bjertnaes, L.J. Infusion of methylene blue in human septic shock: A pilot, randomized, controlled study. Crit. Care Med. 2001, 29, 1860-1867. [CrossRef] [PubMed]

71. Levin, R.L.; Degrange, M.A.; Bruno, G.F.; Del Mazo, C.D.; Taborda, D.J.; Griotti, J.J.; Boullon, F.J. Methylene blue reduces mortality and morbidity in vasoplegic patients after cardiac surgery. Ann. Thorac. Surg. 2004, 77, 496-499. [CrossRef]

72. Annane, D.; Cariou, A.; Maxime, V.; Azoulay, E.; D’Honneur, G.; Timsit, J.F.; Cohen, Y.; Wolf, M.; Fartoukh, M.; Adrie, C.; et al. Corticosteroid Treatment and Intensive Insulin Therapy for Septic Shock in Adults. JAMA 2010, 303, 341.

73. Galley, H.F.; Howdle, P.D.; Walker, B.E.; Webster, N.R. The effects of intravenous antioxidants in patients with septic shock. Free. Radic. Biol. Med. 1997, 23, 768-774. [CrossRef]

74. Spapen, H.; Zhang, H.; Demanet, C.; Vleminckx, W.; Vincent, J.L.; Huyghens, L. Does N-acetyl-L-cysteine influence cytokine response during early human septic shock? Chest 1998, 113, 1616-1624. [CrossRef] [PubMed]

75. Csontos, C.; Rezman, B.; Foldi, V.; Bogar, L.; Drenkovics, L.; Röth, E.; Weber, G.; Lantos, J. Effect of N-acetylcysteine treatment on oxidative stress and inflammation after severe burn. Burns 2012, 38, 428-437. [CrossRef] [PubMed]

76. Fujii, T.; Luethi, N.; Young, P.J.; Frei, D.R.; Eastwood, G.M.; French, C.J.; Deane, A.M.; Shehabi, Y.; Hajjar, L.A.; Oliveira, G.; et al. Effect of Vitamin, C.; Hydrocortisone, and Thiamine vs. Hydrocortisone Alone on Time Alive and Free of Vasopressor Support Among Patients With Septic Shock: The VITAMINS Randomized Clinical Trial. JAMA 2020, 323, 423-431. [CrossRef] [PubMed]

77. Chang, P.; Liao, Y.; Guan, J.; Guo, Y.; Zhao, M.; Hu, J.; Zhou, J.; Wang, H.; Cen, Z.; Tang, Y.; et al. Combined Treatment With Hydrocortisone, Vitamin, C.; and Thiamine for Sepsis and Septic Shock: A Randomized Controlled Trial. Chest 2020, 158, 174-182. [CrossRef] [PubMed]

78. Hwang, S.Y.; Ryoo, S.M.; Park, J.E.; Jo, Y.H.; Jang, D.H.; Suh, G.J.; Kim, T.; Kim, Y.J.; Kim, S.; Cho, H.; et al. Combination therapy of vitamin $\mathrm{C}$ and thiamine for septic shock: A multi-centre, double-blinded randomized, controlled study. Intensive Care Med. 2020, 46, 2015-2025. [CrossRef]

79. Santer, P.; Anstey, M.H.; Patrocínio, M.D.; Wibrow, B.; Teja, B.; Shay, D.; Shaefi, S.; Parsons, C.S.; Houle, T.T.; Eikermann, M.; et al. Effect of midodrine versus placebo on time to vasopressor discontinuation in patients with persistent hypotension in the intensive care unit (MIDAS): An international randomised clinical trial. Intensive Care Med. 2020, 46, 1884-1893. [CrossRef] [PubMed]

80. Schortgen, F.; Clabault, K.; Katsahian, S.; Devaquet, J.; Mercat, A.; Deye, N.; Dellamonica, J.; Bouadma, L.; Cook, F.; Beji, O.; et al. Fever Control Using External Cooling in Septic Shock A Randomized Controlled Trial. Am. J. Respir. Crit. Care Med. 2012, 185, 1088-1095. [CrossRef]

81. Itenov, T.S.; Johansen, M.E.; Bestle, M.; Thormar, K.; Hein, L.; Gyldensted, L.; Lindhardt, A.; Christensen, H.; Estrup, S.; Pedersen, H.P.; et al. Induced hypothermia in patients with septic shock and respiratory failure (CASS): A randomised, controlled, open-label trial. Lancet Respir. Med. 2018, 6, 183-192. [CrossRef]

82. Fuernau, G.; Beck, J.; Desch, S.; Eitel, I.; Jung, C.; Erbs, S.; Mangner, N.; Lurz, P.; Fengler, K.; Jobs, A.; et al. Mild Hypothermia in Cardiogenic Shock Complicating Myocardial Infarction: Randomized SHOCK-COOL Trial. Circulation 2019, 139, $448-457$. [CrossRef] [PubMed]

83. Boussekey, N.; Chiche, A.; Faure, K.; Devos, P.; Guery, B.; D’Escrivan, T.; Georges, H.; Leroy, O. A pilot randomized study comparing high and low volume hemofiltration on vasopressor use in septic shock. Intensive Care Med. 2008, 34, 1646-1653. [CrossRef]

84. Chu, L.-P.; Zhou, J.-J.; Yu, Y.-F.; Huang, Y.; Dong, W.-X. Clinical Effects of Pulse High-Volume Hemofiltration on Severe Acute Pancreatitis Complicated With Multiple Organ Dysfunction Syndrome. Ther. Apher. Dial. 2013, 17, 78-83. [CrossRef] 
85. Combes, A.; Bréchot, N.; Amour, J.; Cozic, N.; Lebreton, G.; Guidon, C.; Zogheib, E.; Thiranos, J.C.; Rigal, J.C.; Bastien, O.; et al. Early high-volume hemofiltration versus standard care for post-cardiac surgery shock the HEROICS study. Am. J. Respir. Crit. Care Med. 2015, 192, 1179-1190. [CrossRef] [PubMed]

86. Chung, K.K.; Coates, E.C.; Smith, D.J.; Karlnoski, R.A.; Hickerson, W.L.; Arnold-Ross, A.L.; Mosier, M.J.; Halerz, M.; Sprague, A.M.; Mullins, R.F.; et al. High-volume hemofiltration in adult burn patients with septic shock and acute kidney injury: A multicenter randomized controlled trial. Crit. Care 2017, 21, 1-8. [CrossRef]

87. Joannes-Boyau, O.; Honoré, P.M.; Perez, P.; Bagshaw, S.M.; Grand, H.; Canivet, J.L.; Dewitte, A.; Flamens, C.; Pujol, W.; Grandoulier, A.S.; et al. High-volume versus standard-volume haemofiltration for septic shock patients with acute kidney injury (IVOIRE study): A multicentre randomized controlled trial. Intensive Care Med. 2013, 39, 1535-1546. [CrossRef]

88. Quenot, J.P.; Binquet, C.; Vinsonneau, C.; Barbar, S.D.; Vinault, S.; Deckert, V.; Lemaire, S.; Hassain, A.A.; Bruyère, R.; Souweine, B.; et al. Very high volume hemofiltration with the Cascade system in septic shock patients. Intensive Care Med. 2015, 41, 2111-2120. [CrossRef] [PubMed]

89. Hawchar, F.; László, I.; Öveges, N.; Trásy, D.; Ondrik, Z.; Molnar, Z. Extracorporeal cytokine adsorption in septic shock: A proof of concept randomized, controlled pilot study. J. Crit. Care 2019, 49, 172-178. [CrossRef]

90. Huang, Z.; Wang, S.R.; Su, W.; Liu, J.Y. Removal of humoral mediators and the effect on the survival of septic patients by hemoperfusion with neutral microporous resin column. Ther. Apher. Dial. 2010, 14, 596-602. [CrossRef] [PubMed]

91. Dellinger, R.P.; Bagshaw, S.M.; Antonelli, M.; Foster, D.M.; Klein, D.J.; Marshall, J.C.; Palevsky, P.M.; Weisberg, L.S.; Schorr, C.A.; Trzeciak, S.; et al. Effect of Targeted Polymyxin B Hemoperfusion on 28-Day Mortality in Patients With Septic Shock and Elevated Endotoxin Level: The EUPHRATES Randomized Clinical Trial. JAMA 2018, 320, 1455-1463. [CrossRef]

92. Payen, D.M.; Guilhot, J.; Launey, Y.; Lukaszewicz, A.C.; Kaaki, M.; Veber, B.; Pottecher, J.; Joannes-Boyau, O.; Martin-Lefevre, L.; Jabaudon, M.; et al. Early use of polymyxin B hemoperfusion in patients with septic shock due to peritonitis: A multicenter randomized control trial. Intensive Care Med. 2015, 41, 975-984. [CrossRef]

93. Vincent, J.L.; Laterre, P.F.; Cohen, J.; Burchardi, H.; Bruining, H.; Lerma, F.A.; Wittebole, X.; De Backer, D.; Brett, S.; Marzo, D.; et al. A pilot-controlled study of a polymyxim B-immobilized hemoperfusion cartridge in patients with severe sepsis secondary to intra-abdominal infection. Shock 2005, 23, 400-405. [CrossRef] [PubMed]

94. Morelli, A.; Ertmer, C.; Rehberg, S.; Lange, M.; Orecchioni, A.; Laderchi, A.; Bachetoni, A.; D'Alessandro, M.; Van Aken, H.; Pietropaoli, P.; et al. Phenylephrine versus norepinephrine for initial hemodynamic support of patients with septic shock: A randomized, controlled trial. Crit. Care 2008, 12, 1-11. [CrossRef] [PubMed]

95. Myburgh, A.; Higgins, A.; Jovanovska, A.; Lipman, J.; Ramakrishnan, N.; Santamaria, J. A comparison of epinephrine and norepinephrine in critically ill patients. Intensive Care Med. 2008, 34, 2226-2234. [CrossRef] [PubMed]

96. Levy, B.; Clere-Jehl, R.; Legras, A.; Morichau-Beauchant, T.; Leone, M.; Frederique, G.; Quenot, J.P.; Kimmoun, A.; Cariou, A.; Lassus, J.; et al. Epinephrine Versus Norepinephrine for Cardiogenic Shock After Acute Myocardial Infarction. J. Am. Coll. Cardiol. 2018, 72, 173-182. [CrossRef]

97. Annane, D.; Vignon, P.; Renault, A.; Bollaert, P.E.; Charpentier, C.; Martin, C.; Troché, G.; Ricard, J.D.; Nitenberg, G.; Papazian, L.; et al. Norepinephrine plus dobutamine versus epinephrine alone for management of septic shock: A randomised trial. Lancet 2007, 370, 676-684. [CrossRef]

98. Levy, B.; Perez, P.; Perny, J.; Thivilier, C.; Gerard, A. Comparison of norepinephrine-dobutamine to epinephrine for hemodynamics, lactate metabolism, and organ function variables in cardiogenic shock. A prospective, randomized pilot study* Crit. Care Med. 2011, 39, 450-455. [CrossRef]

99. Russell, J.A.; Vincent, J.L.; Kjølbye, A.L.; Olsson, H.; Blemings, A.; Spapen, H.; Carl, P.; Laterre, P.F.; Grundemar, L. Selepressin, a novel selective vasopressin V1A agonist, is an effective substitute for norepinephrine in a phase IIa randomized, placebocontrolled trial in septic shock patients. Crit. Care 2017, 21, 213. [CrossRef] [PubMed]

100. Torgersen, C.; Dünser, M.W.; Wenzel, V.; Jochberger, S.; Mayr, V.; Schmittinger, C.A.; Lorenz, I.; Schmid, S.; Westphal, M.; Grander, W.; et al. Comparing two different arginine vasopressin doses in advanced vasodilatory shock: A randomized, controlled, open-label trial. Intensive Care Med. 2010, 36, 57-65. [CrossRef] [PubMed]

101. Hua, F.; Wang, X.; Zhu, L. Terlipressin decreases vascular endothelial growth factor expression and improves oxygenation in patients with acute respiratory distress syndrome and shock. J. Emerg. Med. 2013, 44, 434-439. [CrossRef] [PubMed]

102. Nuding, S.; Schröder, J.; Presek, P.; Wienke, A.; Müller-Werdan, U.; Ebelt, H.; Werdan, K. Reducing Elevated Heart Rates in Patients with Multiple Organ Dysfunction Syndrome with the if (Funny Channel Current) Inhibitor Ivabradine. Shock 2018, 49, 402-411. [CrossRef] [PubMed]

103. Vincent, J.-L.; Angus, D.C.; Artigas, A.; Kalil, A.; Basson, B.R.; Jamal, H.H.; Johnson, G.; Bernard, G.R. Effects of drotrecogin alfa (activated) on organ dysfunction in the PROWESS trial*. Crit. Care Med. 2003, 31, 834-840. [CrossRef] [PubMed]

104. Vincent, J.-L.; Privalle, C.T.; Singer, M.; Lorente, J.A.; Boehm, E.; Meier-Hellmann, A.; Darius, H.; Ferrer, R.; Sirvent, J.-M.; Marx, G.; et al. Multicenter, Randomized, Placebo-Controlled Phase III Study of Pyridoxalated Hemoglobin Polyoxyethylene in Distributive Shock (PHOENIX)*. Crit. Care Med. 2015, 43, 57-64. [CrossRef] [PubMed]

105. Kinasewitz, G.T.; Privalle, C.T.; Imm, A.; Steingrub, J.S.; Malcynski, J.T.; Balk, R.A.; DeAngelo, J. Multicenter, randomized, placebo-controlled study of the nitric oxide scavenger pyridoxalated hemoglobin polyoxyethylene in distributive shock* Crit. Care Med. 2008, 36, 1999-2007. [CrossRef] 
106. López, A.; Lorente, J.A.; Steingrub, J.; Bakker, J.; McLuckie, A.; Willatts, S.; Brockway, M.; Anzueto, A.; Holzapfel, L.; Breen, D.; et al. Multiple-center, randomized, placebo-controlled, double-blind study of the nitric oxide synthase inhibitor 546C88: Effect on survival in patients with septic shock*. Crit. Care Med. 2004, 32, 21-30. [CrossRef]

107. Bakker, J.; Grover, R.; McLuckie, A.; Holzapfel, L.; Andersson, J.; Lodato, R.; Watson, D.; Grossman, S.; Donaldson, J.; Takala, J. Administration of the nitric oxide synthase inhibitor NG-methyl-1-arginine hydrochloride (546C88) by intravenous infusion for up to 72 hours can promote the resolution of shock in patients with severe sepsis: Results of a randomized, double-blind, placebo-controlled multicenter study (study no. 144-002)*. Crit. Care Med. 2004, 32, 1-12. [PubMed]

108. Watson, D.; Grover, R.; Anzueto, A.; Lorente, J.; Smithies, M.; Bellomo, R.; Guntupalli, K.; Grossman, S.; Donaldson, J.; Le Gall, J.-R. Cardiovascular effects of the nitric oxide synthase inhibitor NG-methyl-1-arginine hydrochloride (546C88) in patients with septic shock: Results of a randomized, double-blind, placebo-controlled multicenter study (study no. 144-002)*. Crit. Care Med. 2004, 32, 13-20. [CrossRef]

109. Bernard, G.R.; Francois, B.; Mira, J.-P.; Vincent, J.-L.; Dellinger, R.P.; Russell, J.A.; LaRosa, S.P.; Laterre, P.-F.; Levy, M.M.; Dankner, W.; et al. Evaluating the Efficacy and Safety of Two Doses of the Polyclonal Anti-Tumor Necrosis Factor- $\alpha$ Fragment Antibody AZD9773 in Adult Patients With Severe Sepsis and/or Septic Shock. Crit. Care Med. 2014, 42, 504-511. [CrossRef] [PubMed]

110. Cohen, J.; Carlet, J. INTERSEPT: An international, multicenter, placebo-controlled trial of monoclonal antibody to human tumor necrosis factor- $\alpha$ in patients with sepsis. Crit. Care Med. 1996, 24, 1431-1440. [CrossRef]

111. Abraham, E.; Anzueto, A.; Gutierrez, G.; Tessler, S.; San Pedro, G.; Wunderink, R.; Dal Nogare, A.; Nasraway, S.; Berman, S.; Cooney, R.; et al. Double-blind randomised controlled trial of monoclonal antibody to human tumour necrosis factor in treatment of septic shock. Lancet 1998, 351, 929-933. [CrossRef]

112. Annane, D.; Timsit, J.-F.; Megarbane, B.; Martin, C.; Misset, B.; Mourvillier, B.; Siami, S.; Chagnon, J.-L.; Constantin, J.-M.; Petitpas, F.; et al. Recombinant Human Activated Protein C for Adults with Septic Shock. A Randomized Controlled Trial. Am. J. Respir. Crit. Care Med. 2013, 187, 1091-1097. [CrossRef]

113. Dhainaut, J.F.; Antonelli, M.; Wright, P.; Desachy, A.; Reignier, J.; Lavoue, S.; Charpentier, J.; Belger, M.; Cobas-Meyer, M.; Maier, C.; et al. Extended drotrecogin alfa (activated) treatment in patients with prolonged septic shock. Intensive Care Med. 2009, 35, 1187-1195. [CrossRef] [PubMed]

114. Whitson, M.R.; Mo, E.; Nabi, T.; Healy, L.; Koenig, S.; Narasimhan, M.; Mayo, P.H. Feasibility, Utility, and Safety of Midodrine during Recovery Phase from Septic Shock. Chest 2016, 149, 1380-1383. [CrossRef]

115. Rizvi, M.S.; Nei, A.M.; Gajic, O.; Mara, K.C.; Barreto, E.F. Continuation of Newly Initiated Midodrine Therapy After Intensive Care and Hospital Discharge. Crit. Care Med. 2019, 47, e648-e653. [CrossRef] [PubMed]

116. Hammond, D.A.; Smith, M.N.; Peksa, G.D.; Trivedi, A.P.; Balk, R.A.; Menich, B.E. Midodrine as an Adjuvant to Intravenous Vasopressor Agents in Adults With Resolving Shock: Systematic Review and Meta-Analysis. J. Intensive Care Med. 2019, 35 , 1209-1215. [CrossRef] [PubMed]

117. Payen, D.; Mateo, J.; Cavaillon, J.M.; Fraisse, F.; Floriot, C.; Vicaut, E. Impact of continuous venovenous hemofiltration on organ failure during the early phase of severe sepsis: A randomized controlled trial*. Crit. Care Med. 2009, 37, 803-810. [CrossRef] [PubMed]

118. Hu, D.; Sun, S.; Zhu, B.; Mei, Z.; Wang, L.; Zhu, S.; Zhao, W. Effects of Coupled Plasma Filtration Adsorption on Septic Patients with Multiple Organ Dysfunction Syndrome. Ren. Fail. 2012, 34, 834-839. [CrossRef] [PubMed]

119. Landry, D.W.; Levin, H.R.; Gallant, E.M.; Ashton, R.C.; Seo, S.; D’Alessandro, D.; Oz, M.C.; Oliver, J.A. Vasopressin deficiency contributes to the vasodilation of septic shock. Circulation 1997, 95, 1122-1125. [CrossRef] [PubMed]

120. Hammond, D.A.; Sacha, G.L.; Bissell, B.D.; Musallam, N.; Altshuler, D.; Flannery, A.H.; Lam, S.W.; Bauer, S.R. Effects of Norepinephrine and Vasopressin Discontinuation Order in the Recovery Phase of Septic Shock: A Systematic Review and Individual Patient Data Meta-Analysis. Pharmacotherapy 2019, 39, 544-552. [CrossRef] [PubMed]

121. Wu, Z.; Zhang, S.; Xu, J.; Xie, J.; Huang, L.; Huang, Y.; Yang, Y.; Qiu, H. Norepinephrine vs Vasopressin: Which Vasopressor Should Be Discontinued First in Septic Shock? A Meta-Analysis. Shock 2020, 53, 50-57. [CrossRef]

122. Bellissant, E. Effect of hydrocortisone on phenylephrine- mean arterial pressure dose-response relationship in septic shock. Clin. Pharmacol. Ther. 2000, 68, 293-303. [CrossRef] [PubMed]

123. Cooper, M.S.; Stewart, P.M. Corticosteroid Insufficiency in Acutely Ill Patients. N. Engl. J. Med. 2003, 348, 727-734. [CrossRef] [PubMed]

124. Annane, D. Corticosteroids for septic shock. In Critical Care Medicine; Lippincott Williams and Wilkins: Philadelphia, PA, USA, 2001.

125. Morelli, A.; Singer, M.; Ranieri, V.M.; D’Egidio, A.; Mascia, L.; Orecchioni, A.; Piscioneri, F.; Guarracino, F.; Greco, E.; Peruzzi, M.; et al. Heart rate reduction with esmolol is associated with improved arterial elastance in patients with septic shock: A prospective observational study. Intensive Care Med. 2016, 42, 1528-1534. [CrossRef] [PubMed]

126. Bertini, P.; Guarracino, F. Septic Shock and the Heart. Curr. Anesthesiol. Rep. 2019, 9, 165-173. [CrossRef]

127. Angus, D.C.; Barnato, A.E.; Bell, D.; Bellomo, R.; Chong, C.R.; Coats, T.J.; Davies, A.; Delaney, A.; Harrison, D.A.; Holdgate, A.; et al. A systematic review and meta-analysis of early goal-directed therapy for septic shock: The ARISE, ProCESS and ProMISe Investigators. Intensive Care Med. 2015, 41, 1549-1560. [CrossRef] [PubMed] 
128. Hamzaoui, O.; Georger, J.F.; Monnet, X.; Ksouri, H.; Maizel, J.; Richard, C.; Teboul, J.L. Early administration of norepinephrine increases cardiac preload and cardiac output in septic patients with life-threatening hypotension. Crit. Care 2010, 14, 1-9. [CrossRef]

129. Monnet, X.; Jabot, J.; Maizel, J.; Richard, C.; Teboul, J.-L. Norepinephrine increases cardiac preload and reduces preload dependency assessed by passive leg raising in septic shock patients*. Crit. Care Med. 2011, 39, 689-694. [CrossRef]

130. Malbrain, M.L.N.G.; Van Regenmortel, N.; Saugel, B.; De Tavernier, B.; Van Gaal, P.J.; Joannes-Boyau, O.; Teboul, J.L.; Rice, T.W.; Mythen, M.; Monnet, X. Principles of fluid management and stewardship in septic shock: It is time to consider the four D's and the four phases of fluid therapy. Ann. Intensive Care. 2018, 8, 1-16. [CrossRef] [PubMed]

131. Bar, S.; Nguyen, M.; Abou-Arab, O.; Dupont, H.; Bouhemad, B.; Guinot, P.-G. Dynamic Arterial Elastance Is Associated With the Vascular Waterfall in Patients Treated With Norepinephrine: An Observational Study. Front. Physiol. 2021, 12, 514. [CrossRef]

132. Lamontagne, F.; Richards-Belle, A.; Thomas, K.; Harrison, D.A.; Sadique, M.Z.; Grieve, R.D.; Camsooksai, J.; Darnell, R.; Gordon, A.C.; Henry, D.; et al. Effect of Reduced Exposure to Vasopressors on 90-Day Mortality in Older Critically Ill Patients with Vasodilatory Hypotension: A Randomized Clinical Trial. JAMA J. Am. Med. Assoc. 2020. [CrossRef]

133. Marshall, J.C. Choosing the Best Blood Pressure Target for Vasopressor Therapy. JAMA J. Am. Med. Assoc. 2020, 323, 931-933. [CrossRef]

134. Schmittinger, C.A.; Torgersen, C.; Luckner, G.; Schröder, D.C.H.; Lorenz, I.; Dünser, M.W. Adverse cardiac events during catecholamine vasopressor therapy: A prospective observational study. Intensive Care Med. 2012, 38, 950-958. [CrossRef] [PubMed]

135. Buckley, M.S.; Barletta, J.F.; Smithburger, P.L.; Radosevich, J.J.; Kane-Gill, S.L. Catecholamine Vasopressor Support Sparing Strategies in Vasodilatory Shock. Pharmacother. J. Hum. Pharmacol. Drug. Ther. 2019, 39, 382-398. [CrossRef]

136. Nguyen, M.; Abou-Arab, O.; Bar, S.; Dupont, H.; Bouhemad, B.; Guinot, P.-G. Echocardiographic measure of dynamic arterial elastance predict pressure response during norepinephrine weaning: An observational study. Sci. Rep. 2021, 11, 1-7. [CrossRef]

137. Nguyen, M.; Berhoud, V.; Bartamian, L.; Martin, A.; Ellouze, O.; Bouhemad, B.; Guinot, P.-G. Agreement between different non-invasive methods of ventricular elastance assessment for the monitoring of ventricular-arterial coupling in intensive care. J. Clin. Monit. Comput. 2019, 34, 1-9. [CrossRef] [PubMed]

138. Guinot, P.-G.; Bernard, E.; Levrard, M.; Dupont, H.; Lorne, E. Dynamic arterial elastance predicts mean arterial pressure decrease associated with decreasing norepinephrine dosage in septic shock. Crit. Care 2015, 19, 14. [CrossRef]

139. Bar, S.; Leviel, F.; Abou Arab, O.; Badoux, L.; Mahjoub, Y.; Dupont, H.; Lorne, E.; Guinot, P.-G. Dynamic arterial elastance measured by uncalibrated pulse contour analysis predicts arterial-pressure response to a decrease in norepinephrine. $\mathrm{Br}$. $J$. Anaesth. 2018, 7, 1-7. [CrossRef] [PubMed]

140. Guinot, P.-G.; Longrois, D.; Kamel, S.; Lorne, E.; Dupont, H. Ventriculo-Arterial Coupling Analysis Predicts the Hemodynamic Response to Norepinephrine in Hypotensive Postoperative Patients: A Prospective Observational Study. Crit. Care Med. 2018, 46, e17-e25. [CrossRef] [PubMed]

141. Kelly, R.P.; Ting, C.T.; Yang, T.M.; Liu, C.P.; Maughan, W.L.; Chang, M.S.; Kass, D.A. Effective arterial elastance as index of arterial vascular load in humans. Circulation 1992, 86, 513-521. [CrossRef] [PubMed]

142. Garcia, M.I.M.; Jian, Z.; Settels, J.J.; Hatib, F.; Cecconi, M.; Pinsky, M.R. Reliability of effective arterial elastance using peripheral arterial pressure as surrogate for left ventricular end-systolic pressure. J. Clin. Monit. Comput. 2019, 33, 803-813. [CrossRef] [PubMed]

143. Chang, M.C.; Mondy, J.S.; Meredith, J.W.; Miller, P.R.; Owings, J.T.; Holcroft, J.W. Clinical application of ventricular end-systolic elastance and the ventricular pressure-volume diagram. Shock 1997, 7, 413-419. [CrossRef] [PubMed]

144. Chen, C.-H.; Fetics, B.; Nevo, E.; Rochitte, C.E.; Chiou, K.-R.; Ding, P.-A.; Kawaguchi, M.; Kass, D.A. Noninvasive single-beat determination of left ventricular end-systolic elastance in humans. J. Am. Coll. Cardiol. 2001, 38, 2028-2034. [CrossRef]

145. Kass, D.A.; Kelly, R.P. Ventriculo-arterial coupling: Concepts, assumptions, and applications. Ann. Biomed. Eng. 1992, $20,41-62$. [CrossRef]

146. Wijnberge, M.; Geerts, B.F.; Hol, L.; Lemmers, N.; Mulder, M.P.; Berge, P.; Schenk, J.; Terwindt, L.E.; Hollmann, M.W.; Vlaar, A.P.; et al. Effect of a Machine Learning-Derived Early Warning System for Intraoperative Hypotension vs Standard Care on Depth and Duration of Intraoperative Hypotension During Elective Noncardiac Surgery. JAMA 2020, 323, 1052-1060. [CrossRef]

147. Venkatesh, B.; Khanna, A.K.; Cohen, J. Less is more: Catecholamine-sparing strategies in septic shock. Intensive Care Med. 2019, 45, 1810-1812. [CrossRef] [PubMed] 